\title{
PENERAPAN MEDIA PEMBELAJARAN UNTUK ANAK BERKEBUTUHAN KHUSUS DENGAN BERBANTUAN MODEL POE2WE
}

\author{
Arna Febianti ${ }^{1}$, Nana $^{2}$ \\ 1Mahasiswa Pendidikan Fisika, Universitas Siliwangi \\ ${ }^{2}$ Dosen Pendidikan Fisika, Universitas Siliwangi \\ *email korespondensi: arnafebianti07@ gmail.com
}

\begin{abstract}
Abstrak: Setiap warga negara mempunyai hak yang sama untuk memperoleh pendidikan yang bermutu. Warga negara yang memiliki kelaianan fisik, emosional, mental, intelektual atau sosial berhak memperoleh pendidikan khusus. Pendidikan anak berkebutuhan khusus (pendidikan inklusif) adalah proses pendidikan yang memungkinkan semua anak berkesempatan untuk berpartisipasi secara penuh dalam kegiatan pembelajaran di kelas, tanpa memandang kelainan, ras, ataupun karakteristik lainnya. Penelitian ini dilatarbelakangi permasalahan bahwa belum semua anak berkebutuhan khusus mampu memahami materi fisika dengan baik. Oleh karena itu penelitian ini diarahkan untuk mencari solusi bagaimana menyampaikan materi pembelajaran khusunya fisika untuk anak berkebutuhan khusus agar dapat dengan mudah dipahami dengan menerapkan sebuah media pembelajaran dan berbantuan dengan model $\mathrm{POE}_{2} \mathrm{WE}$. Fisika dalam pembelajarannya memerlukan analisis yang mendalam untuk anak berkebutuhan khusus. Sehingga, dibutuhkan sebuah model untuk memfasilitasi kelemahan pembelajaran fisika untuk peserta didik yang berkebutuhan khusus. Metode yang digunakan dalam penulisan ini yaitu dengan studi kepustakaan dengan mengkaji beberapa literatur untuk dianalisis dan dibuat kesimpulan. Hasil penulisan ini menunjukan bahwa model $\mathrm{POE}_{2} \mathrm{WE}$ dapat membantu proses pembelajaran untuk sisiwa berkebutuhan khusus.
\end{abstract}

\section{Kunci: Media Pembelajaran, Model $\mathrm{POE}_{2} \mathrm{WE}$, Anak Berkebutuhan Khusus}

\section{PENDAHULUAN}

Pendidikan adalah hak asasi yang paling mendasar bagi setiap manusia, tidak terkecuali bagi anak luar biasa atau anak berkebutuhan khusus. Dalam Undang-undang Dasar 1945 pasal 31 ayat 1 dan Undang-undang Nomor 20 tahun 2003 tentang sistem Pendidikan Nasional bab IV pasal 5 ayat 1 dinyatakan bahwa setiap warga negara mepunyai hak yang sama untuk memperoleh pendidikan yang bermutu. Warga negara yang memiliki kelainan fisik, emosional, mental, intelektual,dan atau sosial berhak memperoleh pendidikan khusus. Hal ini menunjukkan bahwa anak yang memiliki kemampuan potensi kecerdasan dan bakat istimewa berhak pula memperoleh kesempatan yang sama dengan anak lainnya (anak normal) dalam layanan 
pendidikan. Hal tersebut dipertegas dalam UU RI No. 20 tahun 2003 tentang Sistem Pendidikan Nasional, maupun dalam peraturan Mendiknas No.70 tahun 2009 tentang Pendidikan Inklusif bagi peseta didik yang memiliki kelainan dan memiliki Potensi Kecerdasan atau bakat istimewa (Prastiyono, 2013: 117)

Amanat hak atas pendidikan bagi anak penyandang kelainan atau ketunaan ditetapkan dalam Undang-undang No. 20 Tahun 2003 tentang Sistem Pendidikan Nasional Pasal 32 disebutkan bahwa: "Pendidikan khusus (pendidikan luar biasa) merupakan pendidikan bagi peserta didik yang memiliki tingkat kesulitan dalam mengikuti proses pembelajaran karena kelainan fisik, emosional, mental, dan sosial, dan atau memiliki potensi kecerdasan dan bakat istimewa". Ketetapan dalam Undang-undang No. 20 Tahun 2003 tersebut bagi anak penyandang kelainan sangat berarti karena memberi landasan yang kuat bahwa anak berkelainan perlu memperoleh kesempatan yang sama sebagaimana yang diberikan kepada anak normal lainnya dalam hal pendidikan dan pengajaran (Efendi dalam Anjaryati, 2011). Pemerintah dalam upaya pemerataan layanan pendidikan untuk menuntaskan wajib belajar pendidikan dasar sembilan tahun yang berkualitas bagi semua anak di Indonesia mempunyai makna yang sangat luas dan strategis. Keputusan Menteri Pendidikan dan Kebudayaan No. 002/U/1986 telah dirintis pengembangan sekolah penyelenggaraan pendidikan inklusif yang melayani penuntasan wajib belajar bagi peserta didik yang berkebutuhan khusus. Untuk mencerdaskan bangsa yang selaras dengan adanya pesan dari Pendidikan Untuk Semua (Educational for All) sekaligus menjadi salah satu usaha meningkatkan partisipasi anak-anak bersekolah (pemerataan kesempatan pendidikan) termasuk anak berkebutuhan khusus (Sukinah dalam Nugroho, 2016).

Pembelajaran kurikulum 2013 adalah pembelajaran yang mendasar pada konsep bahwa pembelajaran merupakan suatu proses pengembangan potensi dan pembangunan karakter setiap siswa sebagai hasil sinergi antara pendidikan yang berlangsung disekolah, keluarga dan masyarakat. Sehingga siswa diberi kesempatan untuk mengembangkan kompetensi mereka menjadi kemampuan yang semakin lama semakin meningkat dalam sikap (spiritual dan sosial), pengetahuan dan keterampilan.

Menurut Nana, dkk., (2014: 1), sesuai dengan Standar Kompetensi Lulusan, sasaran pembelajaran mencakup pengembangan ranah sikap, pengetahuan, dan keterampilan yang dielaborasi untuk setiap satuan pendidikan. Ketiga ranah kompetensi tersebut memiliki lintasan perolehan (proses psikologis) yang berbeda. Sikap diperoleh melalui aktivitas menerima, 
menjalankan, menghargai, menghayati, dan mengamalkan. Pengetahuan diperoleh melalui aktivitas mengingat, memahami, menerapkan menganalisis, mengevaluasi, dan mencipta. Keterampilan diperoleh melalui aktivitas mengamati, menanya, mencoba, menalar, menyaji, dan mencipta. Bantuan guru dalam pembelajaran dapat dilakukan dengan menggunakan media pembelajaran yang sesuai, sehingga anak berkebutuhan khusus dapat menyesuaikan dengan kemampuan yang dimilikya.

Penelitian ini dilatarbelakangi permasalahan bahwa belum semua anak berkebutuhan khusus mampu memahami materi fisika dengan baik. Oleh karena itu penelitian ini diarahkan untuk mencari solusi bagaimana menyampaikan materi pembelajaran khusunya fisika untuk anak berkebutuhan khusus agar dapat dengan mudah dipahami dengan menerapkan sebuah media pembelajaran dan berbantuan dengan model $\mathrm{POE}_{2} \mathrm{WE}$.

\section{METODE PENELITIAN}

Penelitian ini menggunakan metode literasi (studi pustaka) dengan cara mengkaji berbagai literatur yang berkaitan dengan penerapan model $\mathrm{POE}_{2} \mathrm{WE}$, Pendidikan Anak Berkebutuhan Khusus (Pendidikan Inklusi), dan media pembelajaran. Data kemudian dianalisis kemudian disajikan dalam hasil dan pembahasan agar dapat dibuat kesimpulan.

\section{HASIL DAN PEMBAHASAN}

\subsection{Anak Berkebutuhan Khusus}

Anak berkebutuhan khusus merupakan anak yang membutuhkan pelayanan khusus karena adanya keterbatasan mental, fisik, maupun materi. Anak-anak ini membutuhkan layanan pendidikan yang sesuai dengan kebutuhan. Anak Berkebutuhan Khusus (ABK) terdiri dari dua kelompok, yaitu ABK temporer (sementara) dan ABK permanen (tetap). Adapun yang termasuk kategori ABK temporer adalah anak-anak jalanan (anjal), anak-anak korban bencana alam, dan anak-anak di daerah perbatasan dan di pulau terpencil. Sedangkan yang termasuk kategori ABK permanen adalah anak-anak difabel netra, tunarungu, tunadaksa, tunalaras, autis, Attention Dificiency and Hiperactivity Diorders(ADHD), anak berkesulitan belajar, anak berbakat dan sangat cerdas (Gifted), dan lain-lain (Efendi, 2006).

Model pembelajaran adalah model yang digunakan oleh seorang guru untuk menyampaikan materi yang diajarkan kepada peserta didik. Model pembelajaran kontekstual 
merupakan suatu model pembelajaran holistik yang bertujuan untuk mengajarkan peserta didik dalam memahami materi dengan mengaitkan dengan konteks kehidupan nyata, sehingga peserta didik memperoleh pengetahuan dan keterampilan yang dapat diaplikasikan dan ditransfer dari suatu konteks permasalahan yang ke permasalahan lainnya. Berdasarkan penelitian (Nurcahyanto, 2015) model kontekstual merupakan salah satu model pembelajaran yang dapat mengaktifkan siswa dan memberikan pembelajaran yang berkaitan erat dalam kehidupan seharihari. Dalam pembelajaran kontekstual guru bukan lagi seorang yang paling tahu, guru layak utuk mendengarkan siswanya (Nurhadi, 2004).

Guru merupakan elemen penting dalam mempengaruhi anak berkebutuhan khusus. Seorang guru harus memiliki sikap terhadap anak-anak berkebutuhan khusus. Guru memiliki tanggung jawab menciptakan suasana kelas yang dapat menampung secara penuh dan menekankan suasana yang mampu menghargai perbedaan individu (Ilahi dalam Asriningtyas 2015: 51).

Guru fisika yang mengajar di sekolah luar biasa ataupun sekolah inklusi memiliki tantangan yang lebih besar dibandingkan guru di sekolah umum, karena keterbatasan yang dimiliki oleh peserta didiknya membuat guru harus ekstra kreatif dalam mengelola pembelajaran (Salim, 2010). Apabila pada peserta didik normal lebih mudah untuk memilih, meggunakan, dan mengembangkan strategi pembelajaran, berbeda dengan guru yang mengajar peserta didik difabel netra. Kecenderungan peserta didik difabel netra menggantikan indra pengelihatan dengan indra pendengaran sebagai salah satu saluran utama penerima informasi dari luar mengakibatkan pembentukan konsep hanya berdasarkan lisan. Akibatnya ada kecenderungan untuk menggunakan kata tanpa tahu makna sebenarnya. Penguasaan konsep yang terbentuk pada akhirnya hanya berdasarkan pesrsepsi peserta didik itu sendiri yang diperoleh berdasarkan pengalaman dan pemahaman sederhana dari informasi yang ditangkap (Winarti, 2015).

Keterbatasan yang dimiliki oleh ABK mengakibatkan informasi yang didapatkan juga sangat terbatas. Keterbatasan informasi yang didapatkan oleh anak berkebutuhan khusus lebih banyak dialami oleh anak difabel netra, karena kurang lebih 85\% pengamatan dan informasi manusia dilaksanakan oleh mata. Kondisi tidak dapat melihat atau tidak dapat melihat dengan sempurna pada anak difabel netra mengakibatkan mereka kurang atau bahkan tidak memiliki pengalaman visual. Pemanfaatan indera penglihatan memudahkan seseorang melakukan 
penerimaan informasi dan membuat apersepsi terhadap peristiwa atau objek, terutama untuk membentuk suatu pengertian yang utuh (Munawir, 2011). Dalam proses pembelajaran fisika dibutuhkan indera penglihatan untuk memahami konsep dan teori, karena fisika merupakan ilmu yang mempelajari fenomena alam yang dimana peserta didik harus dapat memaknai setiap gejala dengan menggunakan pengamatan.

Pada praktik di lapangan, pembelajaran fisika di sekolah inklusi tidak jauh berbeda dengan pembelajaran fisika pada umumnya. Hanya saja di kelas kita sekarang ada sebagian peserta didik yang belum tentu dapat menerima pembelajaran yang kita lakukan disebabkan karena ada beberapa kondisi yang mereka miliki. Biasanya, ketika ABK diikutkan dalam kelas regular, GPK pasti harus mendampingi. Walau bagaimanapun, GPK adalah orang yang paling tahu dan paling paham tentang ABK. Tugas GK dalam hal ini adalah guru fisika adalah memberikan mendiskusikan konten fisika yang akan kita ajarkan dan mendiskusikan strategi seperti apa yang cocok untuk dibawakan bagi ABK terebut

Selain pendekatan pembelajaran secara umum di atas, ada beberapa inovasi yang telah dilakukan oleh para peniliti dalam mengoptimalkan proses pembelajaran fisika di sekolah inklusi. Penilitian Negoro dkk (2017) telah mengembangkan media pembelajaran fotonovela berbantuan audio untuk membantu siswa tunarungu dalam mempelajari konsep bunyi. Untuk membantu siswa tunanetra, Munif dkk (2017) telah mengembangkan bahan ajar audio berbasis inkuiri. Penelitian serupa dilakukan oleh Camalia dkk (2017) yang telah mengembangkan audiobook yang dilengkapi alat peraga untuk membantu siswa tunanetra dalam mempelajari getaran dan gelomban.

\subsection{Media Pembelajaran}

Menurut Rudi, dkk. (2008). Pembelajaran merupakan suatu kegiatan yang melibatkan seseorang dalam upaya untuk memperoleh pengetahuan, keterampilan, dan nilai-nilai positif dengan memanfaatkan berbagai sumber untuk belajar. Pembelajaran melibatkan dua pihak yaitu siswa sebagai pembelajar dan guru sebagai fasilotator.

Menurut Bovee (Ashar, 2012: 4) menyatakan fungsi media sebagai perantara atau pengantar suatu pesan dari pengirim kepada penerima". Menurut Arsyad (2006: 75-76) prinsip prinsip 
penggunaan media pembelajaran adalah proses pembelajaran menjadi lebih menyenangkan, proses pembelajaran lebih interaktif, dan tersedia umpan balik.

Menurut Wuri dan Futurrahman (2011: 44) kriteria memilih media pembelajaran yaitu ketepatan dengan tujuan pembelajaran, dukungan terhadap bahan pelajaran, kemudahan memperoleh media,keterampilan guru dalam menggunkan, tersedua waktu untuk menggunakannya sesua dengan pemikiran siswa.

\subsection{Model POE $\mathrm{WE}_{2}$}

Model pembelajaran adalah model yang digunakan oleh seorang guru untuk menyampaikan materi yang diajarkan kepada peserta didik. Model pembelajaran kontekstual merupakan suatu model pembelajaran holistik yang bertujuan untuk mengajarkan peserta didik dalam memahami materi dengan mengaitkan dengan konteks kehidupan nyata, sehingga peserta didik memperoleh pengetahuan dan keterampilan yang dapat diaplikasikan dan ditransfer dari suatu konteks permasalahan yang ke permasalahan lainnya.

Model pembelajaran Prediction, Observation, Explanation, Elaboration, Write dan Evaluation (POE2WE) dikembangkan dari model pembelajaran POEW dan model pembelajaran Fisika dengan Pendekatan Konstruktivistik. Pengembangan ini dilakukan untuk sebagai penyempurnaan kedua model sebelumnya. Model POE2WE merupakan model pembelajaran yang dikembangkan untuk mengetahui pemahaman peserta didik mengenai suatu konsep dengan pendekatan konstruktivistik. Model ini membangun pengetahuan dengan urutan proses yaitu meramalkan atau memprediksi solusi dari permasalahan, melakukan eksperimen untuk membuktikan prediksi, kemudian menjelaskan hasil eksperimen yang diperoleh secara lisan maupun tertulis, membuat contoh penerapan dalam kehidupan sehari-hari, menuliskan hasil diskusi dan memuat evaluasi tentang pemahaman peserta didik baik secara lisan maupun tertulis (Nana et al., 2014; 2016).

Model pembelajaran POE2WE dapat menjadikan peserta didik sebagai subjek di dalam pembelajaran. peserta didik secara aktif menemukan suatu konsep melalui pengamatan atau eksperimen secara langsung, bukan dari menghafal buku materi maupun penjelasan dari guru. Model ini memungkinkan peserta didik aktif dalam proses pembelajaran, memberikan kesempatan kepada peserta didik untuk konstruktivistik pengetahuannya, mengkomunikasikan 
pemikirannya dan menuliskan hasil diskusinya sehingga peserta didik lebih menguasai dan memahami konsep yang akan berdampak pada peningkatan prestasi belajar peserta didik Model ini memberikan kesempatan kepada peserta didik untuk melakukan konstruksi pengetahuan yang dimilikinya, melakukan pengamatan terhadap fenomena serta mengkomunikasikan gagasan yang dia perolah dari proses diskusi sehingga peserta didik akan lebih mudah menguasai konsep yang diajarkan (Nana, 2014, 2016; Nana et al., 2014; Nana dan Surahman, 2019, 2020; Permatasari, 2011; Rahayu et al., 2013; Samosir, 2010).

Penggabungan tahapan-tahapan pembelajaran model POEW dan model pembelajaran Fisika dengan Pendekatan Konstruktivistik maka dapat di susun langkah-langkah pembelajaran model POE2WE secara terinci sebagai berikut (Nana dan Surahman, 2019; 2020):

a) Prediction

Tahap prediction yaitu peserta didik membuat prediksi atau dugaan awal terhadap suatu permasalahan. Permasalahan yang ditemukan berasal dari pertanyaan dan gambar tentang materi yang disampaikan oleh guru yang ada di Lembar Kerja peserta didik (LKS)/bukupeserta didik sebelum peserta didik membuat prediksi. Pembuatan prediksi jawaban tahap Prediction pada model POEW identik dengan fase Engagenent pada pendekatan konstruktivistik. Guru mengajukan pertanyaan yang dapat mendorong peserta didik untuk dapat membuat prediksi atau jawaban sementara dari suatu permasalahan.

b) Observation

Tahap Observation yaitu untuk membuktikan prediksi yang telah di buat oleh peserta didik. Peserta didik diajak melakukan eksperimen berkaitan dengan masalah atau persoalan yang ditemukan. Selanjutnya peserta didik mengamati apa yang terjadi, kemudian peserta didik menguji kebenaran dari dugaan sementara yang telah dibuat. Tahap Observation pada model POEW identik dengan fase Exploration pada pendekatan konstruktivistik.

c) Explanation

Tahap Explanation atau menjelaskan yaitu peserta didik memberikan penjelasan terhadap hasil eksperimen yang telah dilakukan. Penjelasan dari peserta didik dilakukan melalui diskusi dengan anggota kelompok kemudian tiap kelompok mempresentasikan hasil diskusinya didepan kelas. Jika prediksi yang di buat peserta didik ternyata terjadi di 
dalam eksperimen, maka guru membimbing peserta didik merangkum dan memberi penjelasan untuk menguatkan hasil eksperimen yang dilakukan. Namun jika prediksi peserta didik tidak terjadi dalam eksperimen, maka guru membantu peserta didik mencari penjelasan mengapa prediksi atau dugaannya tidak benar. Tahap explanation identik dengan fase explanation pada pendekatan konstuktivistik.

d) Elaboration

Tahap elaboration yaitu peserta didik membuat contoh atau menerapkan konsep dalam kehidupan sehari-hari. Tahap elaboration di ambil dari pendekatan konstruktivistik. Tahap ini guru medorong peserta didik untuk menerapkan konsep baru dalam situasi baru sehingga peserta didik lebih memahami konsep yang di ajarkan guru. Tahap ini pengembangan dari pendekatan konstruktivistik.

e) Write

Tahap write atau menulis yaitu melakukan komunikasi secara tertulis, merefleksikan pengetahuan dan gagasan yang dimiliki peserta didik Menurut Masingilia dan Wisniowska (1996) dalam (Yamin \& Ansari, 2012) menulis dapat membantu peserta didik untuk mengekspresikan pengetahuan dan gagasan mereka. peserta didik menuliskan hasil diskusi dan menjawab pertanyaan yang ada pada LKS. Selain itu pada tahap write ini, peserta didik membuat kesimpulan dan laporan dari hasil eksperimen. Tahap ini merupakan pengembangan dari model TTW.

f) Evaluation

Tahap Evaluation yaitu evaluasi terhadap pengetahuan, keterampilan dan perubahan proses berfikir peserta didik. Pada tahap ini peserta didik di evaluasi tentang materi gerak lurus berupa lisan maupun tulisan. Tahap ini merupakan pengembangan dari pendekatan konstruktivistik.

\subsection{Penerapan Model POE2WE}

Salah satu masalah dalam proses pengajaran di sekolah yaitu bagaimana mengembangkan keterampilan siswa agar menjadi kreatif dan sesuai dengan bakatnya. Setiap siswa dilatih sesuai dengan keterampilan dan bakat yang dimiliki agar dapat meningkatkan motivasi. Keterampilan yang harus dimiliki oleh siswa berkaitan dengan penalaran verbal-numerik, pemikiran secara abstrak, mengingat informasi sesuai dengan keabsahan data (Cetinkaya, 2014: 3722-3723). 
Pengembangan keterampilan siswa dapat melalui berbagai inovasi dalam pembelajaran yaitu dengan menggunakan model yang tepat dan sesuai dengan karakteristik siswa (Nana, 2018: 193).

Model POE2WE adalah salah satu solusi kreatif dengan pendekatan konstruktivis yang dianggap memiliki efek pada kreativitas siswa di masa depan. Beberapa peneliti menyakini bahwa kreativitas berupa masalah yang akan dipecahkan, sejumlah ide yang relevan, proses memberikan solusi dari divergen ke kovergen (Lin, 2017: 2-3).

Pada dasarnya, inovasi dalam pembelajaran yang menunjang kreativitas baik secara implisit dan eksplisit tetap menjelaskan pentingnya mengetahui berbagai informasi baik dari sumber media cetak maupun media elektronik yaitu internet (Ohman, 2011: 381). Adanya berbagai alasan yang membuat keyakinan dan pandangan guru sebagai pengajar dalam menerapkan model pembelajaran disesuaikan dengan kebutuhan dan tujuan yang dicapai. Di lain pihak, penggunaan inovasi dalam pembelajaran yaitu dengan blog terkadang membutuhkan kekhususan pengajar agar dapat menyampaikan informasi secara interaktif (Errington, 2007: 41; Nana, 2018: 193).

\section{KESIMPULAN}

Dari berbagai pembahsan yang telah dijabarkan dapat ditarik kesimpulan dan dimaknai bahwa pembelajaran dengan menggunakan Model $\mathrm{POE}_{2} \mathrm{WE}$ dapat membantu pembelajaran untuk anak berkebutuhan khusus. Karena Model Pembelajaran $\mathrm{POE}_{2} \mathrm{WE}$ merupakan salah satu model pembelajaran yang cocok dengan pembelajaran Fisika di SMA dan model pembelajaran ini merupakan pembelajaran yang berpusat pada siswa sehingga siswa tidak hanya diberi informasi melainan dipancing agar ikut serta mencari informasi dengan berbekal ilmu pengetahuan yang dimiliki maka melalui model $\mathrm{POE}_{2} \mathrm{WE}$ dapat membantu proses pembelajaran untuk anak berkebutuhan khusus.

\section{UCAPAN TERIMA KASIH}

Terima kasih kepada Drs. Nana., S.Pd., M.Pd., selaku dosen pengampu mata kuliah Fisika Sekolah II dan semua pihak yang telah membantu demi kesempurnaan artikel ini menjadi lebih baik. 


\section{REFERENSI}

Anjaryati, Fibriana. (2011). Pendidikan Inklusi Dalam Pembelajaran Beyondcenters And Circle Times (Bcct) Di Paud InklusiAhsanu Amala Yogyakarta. Tesis . Yogyakarta: UIN Kalijaga.

Arsyad, Azhar. 2006. Media Pembelajaran. Jakarta: Rineka Cipta.

Camali, dkk. "PENGEMBANGAN AUDIOBOOK DILENGKAPI ALAT PERAGA MATERI GETARAN DAN GELOMBANG UNTUK TUNANETRA KELAS." Unnes Physics Education Journal 5, no. 2 (2017): 66-75.

Cetinkaya, C. (2014). The effect of gifted students creative problem solving program on creative thinking. Social and Behavioral Sciences, 116, 3722-3723. Doi: 10.1016/j.sbspro.2014.01.830

Efendi, M. (2006). Psikopedagogik Anak Berkelainan. Jakarta: Bumi Aksara.

Errington, E. (2004) The impact of teacher beliefs on flexible learning innovation: some practices and possibilities for academic developers. Innovations in Education and Teaching International, 41 (1), 39-47. Doi. 10.1080/1470329032000172702.

Lin, C. Y. (2017). Threshold effects of creative problem-solving attributes on creativity in the math abilities of taiwanese upper elementary students. https://doi.org/10.1155/2017/4571383.

Munawir, Y. (2011). Guru difabel netra Dewasa dan Pembina Karir. Jakarta: Departemen guru dan Kebudayaan Jendral guru Tinggi Proyek Pendidian Tenaga Akademik.

Munif, dkk. "PENGEMBANGAN BAHAN AJAR AUDIO BERBASIS INKUIRI BERBANTUAN ALAT PERAGA PADA MATERI GERAK UNTUK ANAK TUNANETRA KELAS VII SMP/Mts LB." Unnes Physics Education Journal 5, no. 3 (2017): 1-11.

Nana, N. PENERAPAN MODEL CREATIVE PROBLEM SOLVING BERBASIS BLOG SEBAGAI INOVASI PEMBELAJARAN DI SEKOLAH MENENGAH ATAS 
DALAM PEMBELAJARAN FISIKA. In Prosiding SNFA (Seminar Nasional Fisika dan Aplikasinya) (Vol. 3, pp. 190-195).

Nana, S., Akhyar, M., \& Rochsantiningsih, D. (2014). Pengembangan PembelajaranFisika SMA Melalui Elaboration Write and Evaluation (EWE) dalam Kurikulum 2013. Seminar Nasional Pendidikan Sains.

Nana, Surahman, E. (2019). Pengembangan Inovasi Pembelajaran Digital Menggunakan Model Blended POE2WE di Era Revolusi Industri 4.0. Prosiding SNFA (Seminar Nasional Fisika dan Aplikasinya) (Vol.4, pp. 82-90).

Nana, N., \& Pramono, H. (2019). Upaya Peningkatan Kemampuan Kognitif danKomunikasi Ilmiah Siswa Kelas $\mathrm{X}$ MIA 1 SMA Negeri 1 CiamisMenggunakan Model Pembelajaran Inquiry. DIFFRACTION, 1 (1)

Nana. (2018). Penerapan Model Creative Problem Solving Berbasis Blog sebagai Inovasi Pembelajaran di Sekolah Menengah Atas dalam Pembelajaran Fisika. Prosiding SNFA (Seminar Nasional Fisika dan Aplikasinya). 190-195

Negoro, dkk. (2017). "PENGEMBANGAN MEDIA PEMBELAJARAN FOTONOVELA BERBANTUAN AUDIO MATERI BUNYI UNTUK SISWA TUNARUNGU SMP LB/MTs LB." Unnes Physics Education Journal 6, no. 2 (2017): 74-80.

Nugroho, A. 2016. Pendidikan special untuk yang spesial. Prosiding Seminar Nasional Menjadi Guru Inspirator "Kenali Dan Kembangkan Kemampuan Intelegensi Generasi Emas Untuk Indonesia Emas. Purwokerto: UMP.

Nurcahyanto, G. (2015). Pembelajaran Kimia Melalui Pendekatan Ctl (Contextual Teaching and Learning ) Melalui Metode Proyek Dan Metode Inquiry Terbimbing Ditinjau Dari Kreativitas Siswa. Prosiding Seminar Nasional Pendidikan Sains, (November), 2015-495

Nurhadi. (2004). Pembelajaran Kontekstual (Contextual Teaching and Learning) dan Penerapannya dalam KBK. Malang: Universitas Negeri Malang. 
Prastiyono. 2013. Implementasi Kebijakan Pendidikan Inklusif (Studi di Sekolah Galuh Handayani Surabaya). DIA, Jurnal Administrasi Publik Juni 2013, Vol. 11, No. 1, Hal. 117 - 128. Pascasarjana - Untag Surabaya.

Rudi, dkk., (2008). Media Pembelajaran: Hakikat, Pengembangan, Pemanfaatan dan Penilaian. Bandung: Fakultas Pendidika UPI.

Salim, A. (2010). Pengembangan Model Modifikasi Kurikulum Sekolah Inklusif Berbasis Kebutuhan Individu Peserta Didik. Jurnal Pendidikan Dan Kebudayaan, 16(Edisi Khusus I), 21-34.

Samosir, H. (2010). Model Pembelajaran Predict-Observe-Explain-Write (POEW) untuk meningkatkan penguasaan konsep kalor dan keterampilan berpikir kritis siswa SMA. Universitas Pendidikan Indonesia.

Winarti, W. (2015). Tantangan pendidikan inklusi dalam menghadapi masyrakat ekonomi asean. In Seminar Nasional Pendidikan Fisika. Madiun: IKIP PGRI Madiun.

Wuri dan Faturrahman. 2011. Pembelajaran Pkn Di Sekolah Dasar. Yogyakarta: Nuhalitera.

Yamin, M., \& Ansari, B. I. (2012). Taktik mengembangkan kemampuan individual siswa. Jakarta: Gaung Persada Press. 